\title{
Work Demands, Personal Resources and Work Outcomes: The Mediation of Engagement ${ }^{*}$
}

Demandas laborales, recursos personales y resultados laborales

Received: 02 October 2019 | Accepted: 29 November 2020

\author{
Domingos Isidório DA SiLva JúNioR ${ }^{\mathrm{a}}$ \\ Salgado de Oliveira University, Brazil \\ ORCID: https://orcid.org/0000-0001-6515-8181 \\ Maria Cristina Ferreira \\ Salgado de Oliveira University, Brazil \\ ORCID: https://orcid.org/0000-0003-0752-6710 \\ Felipe Valentini \\ São Francisco University, Brazil \\ ORCID: https://orcid.org/0000-0002-0198-0958
}

a_Correspondence author. Email:
domingosisjunior@hotmail.com

How to cite: da Silva, I. D. Jr., Ferreira, M. C., \& Valentini, F. (2021). Work demands, personal resources and work outcomes: the mediation of engagement. Universitas Psychologica, 20, 1-13. https://doi.org/10.11144/ Javeriana.upsy20.wdpr

\begin{abstract}
The study tested a model of relationships of work demands (work overload and misbehavior of the students) and personal resources (self-efficacy) with job outcomes (turnover intention and job crafting behavior), as well as the mediation of work engagement on those relationships. The sample consisted of 451 Brazilian teachers, male and female $(70.7 \%$ female), with ages ranging from 20 to 69 years $(M=38.63$; $S D=$ 10.36). The data analysis was performed through structural equation modeling and the fit indices were adequate. The results showed that work engagement mediated self-efficacy relationships with turnover intention and job crafting behavior. These findings present evidence for the JD-R Theory, according to which the demands exhaust the worker's energy and produce negative outcomes at work, while the personal resources improve the work engagement and produce more positive outcomes. Training programs could be implemented to develop self-efficacy and attitudes of greater work engagement in the teachers, which could make them more proactive and guarantee that they continue in their jobs.
\end{abstract}

Keywords

work engagement; personal resources; job outcomes; teachers; JD-R model.

\section{RESUMEN}

El estudio evaluó un modelo de relaciones de demandas laborales (sobrecarga y mala conducta de los alumnos) y de recursos personales (autoeficacia) con resultados del trabajo (intención de dejar el trabajo y comportamiento de redesenho), y el papel mediador del engagement en el trabajo en esas relaciones. La muestra estaba formada por 451 profesores brasileños, de ambos sexos (70.7\% del sexo femenino), con edades variando de 20 a 69 años $(M=38.63 ; D E=10.36)$. El análisis de datos se realizó mediante modelado de ecuaciones estructurales y los índices de ajuste fueron adecuados. Se verificó que el engagement medió las relaciones de la autoeficacia con la intención de dejar el trabajo y con el comportamiento de rediseño. Tales hallazgos aportan evidencias para la teoría J-DR, según el cual las demandas drenan la energía del trabajador 
y producen resultados negativos en el trabajo, mientras que los recursos personales mejoran el engagament en el trabajo y producen resultados más positivos. Se podrían implementar programas de capacitación para desarrollar sentimientos de autoeficacia y actitudes de mayor compromiso laboral em los docentes, lo que podría hacerlos más proactivos y garantizar que continúen en sus puestos de trabajo.

Palabras clave

engagament en el trabajo; recursos personales; resultados laborales; profesores; modelo JD-R.

In recent decades, the changes in the job world, such as organizational demands for greater competitiveness and productivity, have led to changes in the workers' behavior. In this sense, the workers have had to cope with adversity, which requires decision-making skills. They need to learn how to work in teams, which requires assertiveness, communication skills, and activities in vertical hierarchical networks. Those changes have aroused organizational scholars' interest by analyzing of the psychological and contextual factors that impact the employees' attitudes and behaviors in today's organizations (Bakker \& Demerouti, 2017).

In the wake of those concerns, one of the constructs that have led to a growing number of investigations is work engagement, which is characterized as a positive motivational state that leads employees to perform their tasks with high levels of energy, persistence, concentration, and pride in their work (Bakker \& Albrecht, 2018). Such a construct is an important indicator of employee well-being since the more engaged ones tend to develop more positive emotions regarding work and be more productive (Bakker $\&$ Demerouti, 2017).

According to the Job Demands and Resources Theory, work engagement results from a balance between the resources and the demands of the work context (Bakker \& Demerouti, 2018; Schaufeli \& Taris, 2014). The demands (aspects of work that require physical, psychological, and cognitive effort) cause physiological and psychological changes that make it challenging to perform the tasks and lead the employees to exhaustion. The job resources, in turn, combat the demands and favor the achievement of the employee's job goals. Thus, demands lead to losses to the physical and psychological health of the workers, while resources contribute to their work engagement (Bakker \& Demerouti, 2018). The JD-R Theory also suggests that personal resources, that is, the individual's positive evaluations of his ability to cope with the job demands, are also predictors of work engagement (Bakker \& Demerouti, 2018; Xanthopoulou et al., 2007).

However, the closer analysis of this literature reveals that few studies have been conducted so far, from the perspective of the JD-R Theory, focusing on the occupational category of teachers. The study of teacher engagement is of relevant, though, as it permits deepening the nomological network of this construct in a professional category of fundamental importance for society. Thus, the teachers, being one of the main persons responsible for the teaching-learning process, ends up influencing the students' personal growth and well-being (Klassen et al., 2013). Therefore, knowledge of some of the factors responsible for teachers' engagement and some of their consequences may contribute to the future implementation of intervention strategies to guarantee a higher quality of life for teachers and students and, ultimately, for society in general. Based on these considerations, the objective of this study was to test a model about the relationships of job demands (overload, student misbehavior) and personal resources (self-efficacy) with job outcomes (turnover intention and job crafting behavior) in Brazilian teachers, as well as the mediating role of work engagement in those relations.

\section{Job demands and teacher engagement}

The demands addressed in this research were work overload and students' misbehavior. The work overload is associated with excessive demands related to the tasks to be performed, usually motivated by the employee's lack of time or knowledge (Korpershoek et al., 2016). Those 
demands may be related to the pace of work, the number of hours scheduled for the execution of the tasks, or the use of new technologies the individual is not qualified.

When the number of tasks to be performed is huge, or the time available for execution is insufficient, the overload is quantitative. On the other hand, when the employee has no knowledge or ability to perform the work, the overload is considered qualitative (Dewe et al., 2010). Both types of overload usually lead to boredom, demotivation, exhaustion, drop in performance, and lack of work engagement (Molino et al., 2015).

The student's misbehavior, in turn, refers to behaviors that interfere with teaching in the classroom and cause the teachers to experience emotional suffering (Lopes et al., 2017). In that sense, those behaviors impede the effective occurrence of the teaching-learning process, as they negatively affect communication in the classroom (Çoban, 2015). According to the JD-R Theory, when they become constant, the job demands tend to undermine the individuals' energy and make them experience moments of tension, which ends up interfering in their motivation and, consequently, in their engagement (Bakker \& Demerouti, 2017). Thus, both the work overload and students' misbehavior, being characterized as job demands, are expected to lead to physical and psychological exhaustion, which would interfere in the teachers' work engagement (Lopes et al., 2017).

In this sense, in a study by Fiabane et al. (2013), work overload was considered as one of the most important predictors of work engagement in Italian health professionals. It was concluded that the absence of overload, be it quantitative or qualitative, prevented employees' energies from being exhausted. This is, it protected them against emotional exhaustion. Similar findings were also found in samples of Swiss nurses and physicians (Setti \& Argentero, 2011), Italian employees (Molino et al., 2015), and Finnish teachers (Hakanen et al., 2006).

Similarly, studies of student misbehavior have shown that this variable is positively associated with burnout and teacher stress (Haydon \&
Alter, 2017), threatening the teachers' wellbeing (Boyle et al., 1995). Based on these considerations, the following hypotheses were formulated:

H1: Student misbehavior is negatively related to teachers' work engagement.

$\mathrm{H} 2$ : Work overload is negatively related to teachers' work engagement.

\section{Personal resources and teacher engagement}

The personal resource investigated in this study was self-efficacy. This construct refers to the individual's perception of his ability to perform specific and necessary actions within reach of a given goal (Ritter \& Lorig, 2014). According to the JD-R Theory, personal resources contribute to employee motivation, helping employees deal with emotional demands and becoming more engaged (Bakker \& Demerouti, 2017). Therefore, they constitute coping strategies that favor occupational activities and improve employee well-being (Kassing et al., 2012).

In line with those assertions, studies carried out with German (Klusmann et al., 2008), Spanish (Salanova et al., 2005), Dutch (Bakker \& Xanthopoulou, 2013), Iranian (Zangenehvandi et al., 2014), and Norwegian teachers (Skaalvik \& Skaalvik, 2014) found that self-efficacy correlated positively with work engagement. This construct is a significant predictor of attitudes associated with demonstrating more energy, inspiration, and work involvement (Bakker \& Demerouti, 2017). The hypothesis raised taking these considerations as a reference is:

H3: Teachers' self-efficacy is positively related to work engagement.

\section{Engagement and job outcomes}

The job outcomes investigated in this study were turnover intention and job crafting behavior. Turnover intention is characterized by the thoughts and desires to request dismissal to the immediate superior (Clemens et al., 2009). 
Engaged employees become more motivated and start to carry out their tasks with more energy, enthusiasm, and work engagement, which is why they do not usually have turnover intentions (Oliveira \& Rocha, 2017). In this sense, the study conducted by Høigaard et al. (2012) in Norwegian teachers showed that work engagement was negatively correlated with turnover intention, in a demonstration that, when teachers carry out their activities with more energy and motivation, the chances of them quitting their jobs are reduced.

The job crafting behavior, in turn, refers to the set of proactive behaviors that employees use to minimize the job demands and maximize the job resources (Bakker, 2017). Job crafting attempts seem particularly effective when employees are highly engaged in their work (Demerouti et al., 2019). In this way, research on this construct has shown a positive association between work engagement and job crafting behavior (Bakker et al., 2016). Also, the study conducted by Leana et al. (2009) showed that early American childhood education teachers who were more engaged modified their behaviors to combat the job demands and to obtain the necessary resources to achieve their tasks, thus improving the quality of service to the students. The hypothesis raised taking these considerations as a reference is:

$\mathrm{H} 4$ : Work engagement is negatively related to turnover intention.

H5: Work engagement is positively related to job crafting behavior.

\section{The mediating role of engagement in the relationships of job demands and resources with job outcomes}

Studies on the mediation of work engagement are still incipient since most investigations have focused on analyzing the antecedents or consequences of this construct and not on its role as a mediator of the relationships between job demands and resources and job outcomes. According to the JD-R Theory, however, the employees who use their resources become more capable of combating the demands and presenting greater work engagement. This also makes them demonstrate more positive results at work, such as better performance and lower turnover (Bakker \& Demerouti, 2017)and a greater sense of meaning and efficacy in accomplishing tasks (Xanthopoulou et al., 2009).

In line with this theory, in the research by Bakker and Xanthopoulou (2013) in Dutch elementary school teachers, self-efficacy increased work engagement, which led teachers to become more attentive to their own ability to perform activities. Similarly, Salanova et al. (2005) found that college teachers, when they felt effective, increased their engagement and, consequently, began to demonstrate more involvement in accomplishing their tasks.

Self-efficacy is, therefore, a personal resource that probably leads the employee to work with greater energy, enthusiasm, emotional well-being, self-regulation, persistence, perseverance, and involvement in carrying out their tasks, that is, to show more work engagement (Skaalvik \& Skaalvik, 2014). Such a state of engagement allows the individual to actively participate in tasks, aim to reach goals and exert greater control over events (Bakker \& Demerouti, 2018). It would thus be expected that work engagement would mediate the relationships of self-efficacy with work outcomes, such as the turnover intention and job crafting behaviors. In other words, the expectation is that work engagement acts as a mediator of the negative relationship between self-efficacy and the turnover intention and the positive relationship between selfefficacy and job crafting behaviors.

On the other hand, work overload and student misbehavior are characterized as demands that impose barriers fulfilling tasks and make the occupational environment unfavorable, consequently leading to negative work activities (Çoban, 2015). In this sense, those demands drain workers' energy, leading them to experience states of tension, physical and emotional exhaustion, and less involvement with work, making it difficult to change behaviors in favor of occupational activities (Bakker \& Demerouti, 2018). Then, it can be assumed that work engagement acts as a mediator of the positive 
relations between those demands and turnover intention and the negative relationships between these demands and the job crafting behaviors. Based on these considerations, the following hypotheses were raised:

H6: Work engagement acts as a mediator of the negative relationship of self-efficacy with turnover intention.

H7: Work engagement acts as a mediator of the positive relationship of self-efficacy with job crafting behaviors.

H8: Work engagement acts as a mediator of the positive relationship of students' misbehavior with the turnover intention.

H9: Work engagement acts as a mediator of the negative relationship of students' misbehavior to job crafting behaviors.

H10: Work engagement acts as a mediator of the positive relationship between work overload and turnover intention.

H11: Work engagement acts as a mediator of the negative relationship between work overload and job crafting behaviors.

\section{Method}

\section{Participants}

The sample consisted of 451 teachers working in elementary $(50.3 \%)$, secondary $(20.9 \%)$, and higher $(28.8 \%)$ education. These teachers were male and female $(70.7 \%$ female), and their ages ranged from 20 to 69 years $(M=38.63 ; S D=$ 10.36). Regarding education, $3.1 \%$ had finished secondary education; $12.9 \%$ incomplete higher education; 22\% complete higher education; $27.5 \%$ specialization; $23.1 \% \mathrm{MSc}$ and $11.5 \mathrm{PhD}$. The length of teaching experience ranged from 1 to 30 years $(M=7.7 ; S D=6.51)$ and the total length of experience from 1 to 42 years $(\mathrm{M}=$ $12.47 ; S D=8.87$ ). As for the work sector, $61.4 \%$ of the teachers came from public schools. To be included in the sample, the participants should have been teaching for at least one year.

\section{Instruments}

The teachers' work engagement was evaluated using a short version of the Engaged Teachers Scale (ETS) (Klassen et al., 2013), adapted and validated for Brazilian samples by Silva et al. (2020). It consists of sixteen items, distributed in four dimensions, to be answered on sevenpoint Likert scales ranging from 1 (never) to 7 (always). In the composition of the short version, the items with the highest factor loadings in each dimension were selected. The scale therefore consisted of a single factor and eight items. Its fit indices were equal to $\chi^{2}(18)=6.760$; $\mathrm{RMSEA}=$ $0.08 ; \mathrm{CFI}=0.99 ; \mathrm{TLI}=0.99$. The scale obtained an internal consistency index of 0.91 in this study.

Self-efficacy was measured using the short version of the Norwegian Teacher Self-Efficacy Scale (NTSES) (Skaalvik \& Skaalvik, 2007), adapted, and validated for Brazilian samples by Silva et al. (2018). It consists of twentyfour items, distributed in six dimensions, to be answered on seven-point Likert scales ranging from 1 (not certain at all) to 7 (absolutely certain). In the composition of the short version, the items with the highest factor loadings in each dimension were selected. Thus, it consists of six items and a single factor. Its fit indices were equal to $\chi^{2}(9)=9.799$; $\mathrm{RMSEA}=0.11$; CFI $=0.98$; $\mathrm{TLI}=0.97$. The internal consistency of the scale corresponded to 0.84 in this study.

The job crafting behaviors were measured using a short version of the Job Crafting Behavior Scale (Petrou et al., 2012), originally consisting of eleven items and three dimensions. In short version assembly, the items with the highest factor loadings in each dimension were selected for this research. Thus, the scale contained a single factor and six items to be answered on five-point Likert scales, ranging from never (1) to always (5). Its fit indices were equal to $\chi^{2}(6)=$ 3.001; $\operatorname{RMSEA}=0.09 ; \mathrm{CFI}=0.99$; TLI $=0.98$. In this study, the scale presented a Cronbach's alpha coefficient of 0.71 .

The work overload was measured using the scale developed by Spector and Jex (1998) and adapted to Brazilian Portuguese for this study. It 
comprises five items, to be answered on five-point Likert scales, ranging from never (1) to several times a day (5). Its fit indices were equal to $\chi^{2}(10)$ $=2952.963 ; \mathrm{RMSEA}=0.13 ; \mathrm{CFI}=0.99 ; \mathrm{TLI}=$ 0.97 . The scale obtained an internal consistency index of 0.83 in this study.

The students' misbehavior was evaluated using a subscale of the Teacher Stress Questionnaire, constructed by Gomes et al. (2006), which contains 36 items, distributed in six factors: students' inappropriate behavior/ indiscipline; time pressure/work overload; different student skills and motivations; the position of the teaching career; bureaucratic/administrative work; inappropriate disciplinary policies. In this study, however, only the students' inappropriate behaviors/indiscipline scale was used, composed of seven items, to be answered on five-point Likert scales, ranging from no stress $(0)$ to high stress. Their fit indices were equal to $\chi^{2}(11)=$ 1290.78; $\mathrm{RMSEA}=0.15 ; \mathrm{CFI}=0.96$; $\mathrm{TLI}=$ 0.92. Cronbach's alpha of this scale was 0.95 in the current investigation.

The turnover intention was measured using the Turnover Intention Scale developed and validated in the Brazilian context by Siqueira et al. (1997). It is composed of three items, to be answered in five-point Likert scales, ranging from never (1) to always (5). Its fit indices were equal to $\chi^{2}(15)=24.295$; RMSEA $=0.04 ; \mathrm{CFI}=0.99$; $\mathrm{TLI}=0.99$. The internal consistency index of that scale was equal to 0.96 in this study.

\section{Data collection and analysis procedures}

The instrument was applied in an electronic version. The respondents were contacted by emails sent individually and on lists of various educational institutions in the researcher's contact network. Initially, the participants who agreed to participate in the study filled out the informed consent form and then completed the scales. The confidentiality of information provided to all respondents was ensured.

Initially, the measuring model was verified using confirmatory factor analysis, with the model of six different and correlated factors being compared to two other models: the model of two distinct and correlated factors (the variables work engagement, self-efficacy, and job crafting behavior were grouped into a single factor and the variables work overload, student misbehavior, and turnover intention were grouped into another factor) and the single-factor model, which aggregated all study variables.

Then, the research hypotheses were tested through structural equation modeling, initially evaluating the direct effect of the independent variables (student misbehavior, work overload, and self-efficacy) on the dependent variables (turnover intention and job crafting behavior). Subsequently, the direct effect of the independent variables on the mediator variable (work engagement) was observed, and the direct effect of the mediator variable on the dependent variables. Finally, we verified the indirect effect of the independent variables on the dependent variables. The used goodness of fit and the reference values adopted were: $\chi^{2 / g l}<5$; CFI $>0.90 ;$ TLI $>0.90 ;$ RMSEA $<0.08(\mathrm{Hu} \&$ Bentler, 1999).

\section{Results}

\section{Measuring models}

First, the means, the standard deviations, and the correlations between the scores of the different scales adopted in the study were obtained. These results can be observed in Table 1 . The complete model, with the six variables inserted as distinct variables $\left(\chi^{2}(537)=1130.73\right.$, RMSEA $=0.05$, CFI $=0.98$, TLI $=0.98)$ presented the best fit indices when compared to the model with two distinct factors, in which a factor was set for all outcome variables and another factor for all independent variables $\left(\chi^{2}(551)=4153.20\right.$; RMSEA $=0.12$; CFI $=0.89$; TLI $=0.88)$, and to the single factor model $\left(\chi^{2}(552)=11693.39\right.$; RMSEA $=0,21 ;$ CFI $=0.67$; TLI $=0.64)$. 
Table 1

Means, standard deviations and correlations between the scales

\begin{tabular}{|c|c|c|c|c|c|c|c|c|}
\hline Construct & $M$ & $S D$ & 1 & 2 & 3 & 4 & 5 & 6 \\
\hline 1. Work engagement & 6.0 & 0.8 & - & & & & & \\
\hline 2. Self-efficacy & 5.3 & 0.9 & $0.63^{* *}$ & - & & & & \\
\hline 3. Job crafting behaviors & 3.1 & 0.6 & $0.22^{* * *}$ & $0.28^{*}$ & - & & & \\
\hline 4. Work overload & 3.5 & 0.8 & $-0.10^{*}$ & -0.05 & $0.09 *$ & - & & \\
\hline 5. Students' misbehavior & 2.4 & 1.1 & -0.09 & 0.04 & 0.04 & 0.20 ** & - & \\
\hline 6. Turnover intention & 1.9 & 1.2 & $-0.28 *$ & $-0.12^{*}$ & -0.04 & $0.20 * *$ & $0.20 * *$ & - \\
\hline
\end{tabular}

\section{Test of relationships between the variables}

The direct effect of the independent variables (student misbehavior, work overload, and selfefficacy) on the dependent variables (turnover intention and job crafting behavior) was initially observed to check the hypotheses. The results evidenced that these effects were significant for work overload on turnover intention (WOL INT: $\beta=0.19, p<0.01)$ and on the job crafting behavior (WOL - JCB: $\beta=0.12 ; p<0.05$ ), and for self-efficacy on the turnover intention (SEF INT: $\beta=-0.11, p<0.05)$. The inclusion of work engagement as a mediating variable in the model indicated that: the students' misbehavior was negatively and significantly associated with the engagement (MIS - ENG: $\beta=-0.08 ; p<0.05$ ), which confirmed hypothesis 1 ; that the overload was also negatively and significantly correlated with the engagement (WOL - ENG: $\beta=-0.08$; $p<0.05)$, which permitted the confirmation of hypothesis 2; that self-efficacy was positively and significantly related to engagement (SEF- ENG: $\beta$ $=0.70 ; p<0.01$ ), thus confirming hypothesis 3 . Regarding the relationship between the mediator variable and the dependent variables, the results showed that there was a negative and significant association between engagement and turnover intention (ENG - INT: $\beta=-0.29 ; p<0.01$ ), which permitted confirming hypothesis 4 , as well as a positive and significant relationship between the engagement and job crafting behaviors (ENG - JCB: $\beta=0.24 ; p<0.01$ ), which confirmed hypothesis 5 .
The indirect effect of self-efficacy on the turnover intention was negative and significant (SEF - ENG - INT: $\beta=-0.20 ; p<0.01$ ). Similarly, the indirect effect of the relationship between self-efficacy and job crafting behavior (SEF - ENG - JCB: $\beta=0.17 ; p<0.01$ ) was also statistically significant. It was also observed that, in the presence of the mediator variable, the direct effects of self-efficacy on turnover intention and of self-efficacy on job crafting behavior were not significant. In summary, engagement mediated the relationship between self-efficacy and the turnover intention, as well as between self-efficacy and job crafting behavior, which confirmed hypotheses 6 and 7 .

The indirect effect of students' misbehavior on the turnover intention (SEF - ENG - INT: $\beta=$ $0.02 ; p>0.05$ ) was not statistically significant. In addition, the indirect effect of the students' misbehavior on the job crafting behavior (MIS - ENG - JCB: $\beta=-0.02 ; p>0.05$ ) was not statistically significant either. It was also verified that, in the presence of the mediator variable, the direct effects of the misbehavior on the turnover intention and of the misbehavior on the job crafting behavior were not significant. In this sense, engagement did not mediate the relationship between those variables, which impeded the confirmation of hypotheses 8 and 9 .

Similarly, the indirect effect of the work overload on the turnover intention (WOL - ENG - INT: $\beta=0.02 ; p>0.05$ ), as well as the indirect effect of the work overload on the job crafting behavior (WOL - ENG - JCB: $\beta=-0.02, p$ $>0.05$ ), were not statistically significant, thus impeding the confirmation of hypotheses 10 and 11. The final model is displayed in Figure 1. Their fit indices were equal to: $\mathrm{c}^{2}(501)=6826.849$; $\mathrm{CFI}=0.92 ; \mathrm{TLI}=0.91 ; \mathrm{RMSEA}=0.08$. 


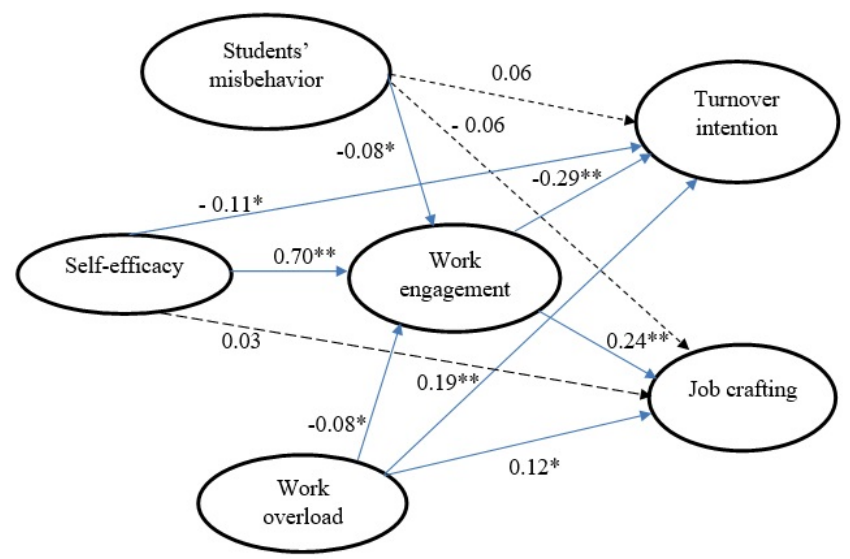

Figure 1

Graphical representation of the model tested with the standardized parameters

\section{Discussion}

This study aimed to test a model of relationships between job demands (work overload and misbehavior of students) and personal resources (self-efficacy) and job outcomes (turnover intention and job crafting behaviors), as well as the mediating role of work engagement in those relationships. The results showed that students' misbehavior was negatively related to work engagement, which confirmed hypothesis 1. This result converges with the previous findings, based on which it was also concluded that a negative relationship exists between the students' misbehavior and the work engagement (Lopes et al., 2017; Hakanen et al., 2006). Students' misbehavior implies an increase in the psychological costs associated with the teaching activity, which would cause the teachers to become unmotivated to carry out their school activities. In other words, disobedience, disrespect for the teacher, among others, can end the energy, inspiration, and engagement of the teacher in the work tasks that need to be developed (Korpershoek et al., 2016; Hakanen et al., 2006).

The work overload was negatively and significantly related to the work engagement, which confirmed hypothesis 2. It was verified that high workloads, whether quantitative or qualitative, interfere with the teachers' work engagement. This result corroborates the study by Hakanen et al. (2006), who also observed negative relationships between work overload and engagement. It is possible that the teachers perceive the fact that they have many tasks to accomplish in their daily work (such as correcting tests and assignments and registering grades), within short deadlines, besides having to participate in other activities, such as board meetings and meetings with parents of students, as an obstacle that will reduce their energy, inspiration, and engagement in teaching tasks (Molino et al., 2015; Timms et al., 2007).

The results about the negative relationships of work overload and misbehavior of students with work engagement can also be viewed as a confirmation of the proposition of the Job Demands and Resources Theory that job demands lead to losses to the physical and psychological health of the workers. In this sense, they contribute to diminishing their work engagement (Bakker, 2017).

It was also observed that self-efficacy was positively related to work engagement, which fully confirmed hypothesis 3 . In this sense, the findings permit affirming that teachers who more strongly believe that they can perform their work activities manifest greater engagement, also evidenced in Xanthopoulou et al. (2007). This may be because when teachers realize they can accomplish their tasks and set goals on how to achieve them, they become more motivated to make efforts and persist in carrying out these activities (Bakker \& Demerouti, 2017; Simbula et al., 2011). In other words, personal resources such as self-efficacy help employees to actively approach their job demands and effectively deal with them, which makes them feel more engaged in their work (Bakker \& Demerouti, 2018).

It was also verified that the work engagement was negatively related to the turnover intention, which confirmed hypothesis 4 and converging with other studies, such as Gupta and Shareen (2017) and Schaufeli and Bakker (2004). It has been demonstrated, then, that when teachers experience high levels of energy, being absorbed in the performance of their tasks, and dedicated 
to them, the thought of leaving their jobs ends up being distanced. This may be since the teacher, when motivated, inspired, and dedicated to his work, ends up developing strategies to perform his tasks with greater disposition and to face the demands inherent to the school context, which is why he does not develop the desire to quit his job (Saks, 2006).

Work engagement was also positively related to job crafting behaviors, thus confirming hypothesis 5 . Thus, it was found that high levels of energy, inspiration, and work engagement maximize the proactive behaviors towards the achievement of the outlined work goals, confirming the study by Bakker et al. (2016). It seems, hence, that the affective-motivational states are fundamental stimulators for the teacher to find resources and, consequently, to face the demands, thus carrying out his/her occupational activities with greater proactivity and greater possibilities to accomplish the outlined work goals (Beer et al., 2016).

Work engagement is, therefore, a predictor of important employee outcomes. In this way, engaged employees are goal-directed and focus all their energy on the tasks (Bakker \& Albrecht, 2018). This can explain why their engagement diminishes their turnover intention and increases their job crafting behaviors (Demerouti et al., 2019; Bakker, 2017).

Another noteworthy point is that work engagement fully mediated the negative relationship of self-efficacy with the turnover intention, which permitted confirming hypothesis 6 . Therefore, the findings showed that when teachers have a clearer view of their task accomplishment skills, they feel more energetic, inspired, and engaged in their work. As a result, they become less inclined to quit their job, probably because they can develop more coping strategies regarding the job demands. This result was also found in the study by Chen and Chen (2012) and Bakker et al. (2016), considering the mediating role of engagement in the relationships between job resources and turnover intention.

Furthermore, the findings showed that work engagement also mediated the positive relationship of self-efficacy with job crafting behavior, which confirmed hypothesis 7. This result may be since the teachers who believe more in their abilities to carry out specific actions to achieve a particular goal develop greater enthusiasm, inspiration, and engagement in their tasks, which triggers proactive behavior to change the way to accomplish school tasks. Such actions probably end up improving classroom management and problem-solving (Bakker et al., 2016).

Nevertheless, the work engagement mediated neither the positive relationship of the students' misbehavior with the turnover intention nor the negative relationship between the students' misbehavior and the job crafting behavior, which impeded the confirmation of hypotheses 8 and 9. This may happen because the teachers do not perceive the students' misbehavior as a demand but as habitual conduct inherent in the school context, which needs to be managed and administered as part of their classroom activities. In other words, they are probably perceived as expected behaviors, which need to be controlled over the class period (Çoban, 2015; van Wingerden et al., 2017).

Similarly, it was verified that the work engagement mediated neither the positive relationship between the work overload and the turnover intention nor the negative relationship of the work overload with the job crafting behaviors, which prevented the confirmation of hypotheses 10 and 11 . Those results may be because the teachers do not perceive the work overload as a demand, but rather as something inherent to the practice of the profession, that is, as something perceived as ordinary, even when faced with a large number of tasks (Molino et al., 2015). That assertion needs further confirmation in future research, though.

Overall, the findings are in accordance with the JD-R Theory (Bakker \& Demerouti, 2018). The demands, such as work overload, require physical and psychological effort, drain the worker's energy, thus constituting dysfunctional aspects. Personal resources, in turn, facilitate the adaptation to the circumstances of life (Bakker \& Demerouti, 2018; Xanthopoulou et al., 2007). Thus, JD-R Theory constitutes 
an overarching framework applied to various occupational settings, irrespective of the specific job demands and job resources involved (Bakker $\&$ Demerouti, 2017).

Regarding the limitations of the research, its cross-sectional design prevents the verification of causal relationships between the research variables. Another limitation concerns the fit indices of some of the scales (work overload and student misbehavior), which were not very good, which indicates the need to reevaluate these scales. In addition, the sample only included Brazilian teachers, which is why the results obtained should be generalized with caution to samples of other nationalities. In addition, the study verified only the impact of personal resources and job demands, not including, in the tested model, the job resources, which are also part of the JD-R Theory.

As for a future research agenda, it would be interesting to carry out studies with longitudinal designs to deepen the understanding of the research variables. In addition, its integration into a job resource and demand model, including other personal resources, such as self-esteem and optimism, would contribute to the test of a more robust research model. It would also be interesting to compare such a model in public and private education teachers as most of the studies so far have been using public school teachers.

In any case, teachers with firmer selfefficacy beliefs tend to experience higher levels of work engagement and, consequently, develop more proactive goal-oriented behaviors and lower turnover intention, which will probably favor their good performance in educational institutions. Regarding the practical implications, training programs could be implemented to develop feelings of self-efficacy and attitudes of greater work engagement in the teachers, which could make them more proactive and guarantee that they continue in their jobs.

\section{References}

Bakker, A. B. (2017). Strategic and proactive approaches to work engagement.
Organizational Dynamics, 46(2), 67-75. http s://doi.org/10.1016/j.orgdyn.2017.04.002

Bakker, A. B., \& Albrecht, S. (2018). Work engagement: Current trends. Career Development International, 23(1), 4-11. http s://doi.org/10.1108/CDI-11-2017-0207

Bakker, A. B., \& Demerouti, E. (2017). Job demands-resources theory: Taking stock and looking forward. Journal of Occupational Health Psychology, 22(3), 273-285. https://d oi.org/10.1037/ocp0000056

Bakker, A. B., \& Demerouti, E. (2018). Multiple levels in job demands-resources theory: Implications for employee well-being and performance. In E. Diener, S. Oishi, \& L. Tay (Eds.), Handbook of wellbeing. DEF Publishers. https://nobascholar.com/chapte rs/36/download.pdf

Bakker, A. B., Rodriguez-Muñhoz, A. \& Sanz Vergel, A. I. (2016). Modelling job crafting behaviours: Implications for work engagement. Human Relations, 69(1), 169-189. https://doi.org/10.1177/00187267 15581690

Bakker, A. B., \& Xanthopoulou, D. (2013). Creativity and charisma among female leaders: The role of resources and work engagement. The International Journal of Human Resource Management, 24(14), 2760-2779. https://doi.org/10.1080/095851 92.2012 .751438

Beer, L. T., Tims, M., \& Bakker, A. B. (2016). Job crafting and its impact on work engagement and job satisfaction in mining and manufacturing. South African Journal of Economic and Management Sciences, 19(3), 400-412. https://doi.org/10.4102/sajems.v1 9i3.1481

Boyle, G. J., Borg, M. G., Falzon, J. M., \& Baglioni, A. J. Jr. (1995). A structural model of the dimensions of teacher stress. British Journal of Educational Psychology, 65(1), 49-67. https://doi.org/10.1111/j.2044-8279 .1995.tb01130.x

Chen, C. F., \& Chen, S. C. (2012). Burnout and work engagement among cabin crew: Antecedents and consequences. The International Journal of Aviation Psychology, 
22(1), 41-58. https://doi.org/10.1080/1050 8414.2012.635125

Clemens, E. V., Milsom, A. \& Cashwell, C. S. (2009). Using leader-member exchange theory to examine principal - school counselor relationships, school counselors' roles, job satisfaction, and turnover intentions. Professional School Counseling, 13(2), 74-86. https://doi.org/10 $.1177 / 2156759$ X0901300203

Çoban, A. (2015). Teachers' reactions towards misbehavior in the classroom. Education and Science, 40(180), 89-102. https://doi.or g/10.15390/EB.2015.4520

Demerouti, E., Bakker, A. B., \& Xanthopoulou, D. (2019). Job demands-resources theory and the role of individual cognitive and behavioral strategies. In T. Taris, $\mathrm{M}$. Peeters, \& H. De Witte (Eds.), The fun and frustration of modern working life: Contributions from an occupational health psychology perspective (pp. 94-104). Pelckmans Pro.

Dewe, P. J., O’Driscoll, M. P., \& Cooper, C. L. (2010). Coping with work stress: A review and critique. Wiley-Blackwel.

Fiabane, E., Giorgi, I., Sguazzin, C. \& Argentero, P. (2013). Work engagement and occupational stress in nurses and other healthcare workers: The role of organizational and personal factors. Journal of Clinical Nursing, 22 (17-18), 2614-2624. h ttps://doi.org/10.1111/jocn.12084

Gomes, A. R., Silva, M. J., Mourisco, S., Silva, S., Mota, A., \& Montenegro, N. (2006). Problemas e desafios no exercício da atividade docente: Um estudo sobre o stresse, burnout, saúde física e satisfação profissional em professores do 3ำ ciclo e ensino secundário [Problems and challenges in teacher activity: One study about stress, burnout, health physical and satisfaction professional in professor 3rd cycle of secondary education]. Revista Portuguesa de Educação, 19(1), 67-93. http: //hdl.handle.net/1822/5619

Gupta, M., \& Shaheen, M. (2017). Impact of work engagement on turnover intention:
Moderation by psychological capital in India. Business: Theory and Practice, 18, 136-143. https://doi.org/10.3846/btp.2017. 014

Hakanen, J. J., Bakker, A. B., \& Schaufeli, W. B. (2006). Burnout and work engagement among teachers. Journal of School Psychology, 43(6), 495-513. https://d oi.org/10.1016/j.jsp.2005.11.001

Haydon, T., \& Alter, P. (2017). Teacher education and special education. The Journal of the Teacher Education, 40(2), 1-14. https://doi.org/10.1177/08884064177 00962

Høigaard, R., Giske, R., \& Sundsli, K. (2012). Newly qualified teachers' work engagement and teacher efficacy influences on job satisfaction, burnout, and the intention to quit. European Journal of Teacher Education, 35(3), 347-357. https://doi.org/10.1080/02 619768.2011 .633993

Hu, L., \& Bentler, P. (1999). Cutoff criteria for fit indices in covariance structure analysis: conventional criteria versus new alternatives. Structural Equation Modeling, 6(1), 1-55. https://doi.org/10.1080/107055 19909540118

Kassing, J. W., Piemaont, N. M., Goman, C. C., \& Mitchel, C. A. (2012). Dissent expression. As an indicator of work engagement and intention to leave. Journal of Business Communication, 49(3), 237-253. https://doi .org/10.1177/0021943612446751

Klassen, R. M., Yederlen, S., \& Durksen, T. L. (2013). Measuring teacher engagement: Development of the engaged teachers scale (ETS). Frontline Learning Research, 1(2), 33-52. https://doi.org/10.14786/flr.v1i2.44

Klusmann, U., Kunter, M., Trautwein, U., Lüdtke, O., \& Baumert, J. (2008). Teachers' occupational well-being and quality of instruction: The important role of selfregulatory patterns. Journal of Educational Psychology, 3, 702-715. https://doi.org/10.1 037/0022-0663.100.3.702

Korpershoek, H., Harms, T., Boer, H., Kuijk, M. V., \& Doolaard, S. (2016). A meta-analysis of the effects of 
Domingos Isidório da Silva Júnior, Maria Cristina Ferreira, Felipe Valentini.

classroom management strategies and classroom management programs on students' academic, behavioral, emotional, and motivational outcomes. Review of Educational Research, 86(3), 643-680. https ://doi.org/10.3102/0034654315626799

Leana, C., Appelbaum, E., \& Shevchuc, I. (2009). Work process and quality of care in early childhood education: The role of job crafting. Academy of Management Journal, 52, 1169-1192. https://doi.org/10.5465/amj .2009 .47084651

Lopes, J., Silva, E., Oliveira, C., Sass, D. A., \& Martin, N. L. (2017). Teacher's classroom management behavior and students' classroom misbehavior: A study with 5th through 9th - grade students. Electronic Journal of Research in Educational Psychology, 15(3), 1696-2095. https://doi.or g/10.14204/ejrep.43.17075

Molino, M., Cortese, C. G., Bakker, A. B., \& Ghislieri, C. (2015). Do recovery experiences moderate the relationship between workload and work-family conflict? Career Development International, 20(7), 686-702. https://doi.org/10.1108/C DI-01-2015-0011

Oliveira, L. B., \& Rocha, J. C. (2017). Work engagement: Individual and situational antecedents and its relationship with turnover intention. Review of Business Management, 19(65), 415-431. https://doi.o rg/10.7819/rbgn.v19i64.3373

Petrou, P., Demerouti, E., Peeters, M. C., Schaufeli, W. B., \& Hetland, J. (2012). Crafting a job on a daily basis: Contextual correlates and the link to work engagement. Journal of Organizational Behavior, 33, 11201141. https://doi.org/10.1002/job.1783

Ritter, P. L., \& Lorig, K. (2014). The English and Spanish self-efficacy to manage chronic disease scale measures were validated using multiple studies. Journal of Clinical Epidemiology, 67(11), 1265-1273. https://do i.org/10.1016/j.jclinepi.2014.06.009

Saks, A. M. (2006). Antecedents and consequences of employee engagement. Journal of Managerial Psychology, 21(7),
600-619. https://doi.org/10.1108/02683940 610690169

Salanova, M., Chifre, E., Grau, R. M., Llorens, S., \& Martinez, I. M. (2005). Antecedents of self-efficacy in college teachers and students: A causal model. Revista de Psicología del Trabajo y de las Organizaciones, 21(1-2), 159-176. http://www.copmadrid.org/webco pm/publicaciones/trabajo/96813.pdf

Schaufeli, W. B., \& Bakker, A. B. (2004). UWES - Utrecht Work Engagement Scale: Test Manual. Utrecht University, Department of Psychology. https://www.wilmarschaufeli.nl /publications/Schaufeli/Test\%20Manuals/ Test_manual_UWES_Espanol.pdf

Schaufeli, W. B., \& Taris, T. W. (2014). A critical review of the job demands-resources model: Implications for improving work and health. In G. F. Bauer \& O. Hâmmig (Eds.), Bridging occupational, organizational and public health (pp. 43-68). Springer. http s://doi.org/10.1007/978-94-007-5640-3_4

Setti, I., \& Argentero, P. (2011). Organizational features of workplace and job engagement among Swiss healthcare workers. Nursing and Health Sciences, 13(4), 425-432. https:// doi.org/10.1111/j.1442-2018.2011.00636.x

Silva, D. I., Jr., Ferreira, M. C., \& Valentini, F. (2020). Psychometric properties of the Engaged Teachers Scale (ETS). Psicologia: Teoria e Prática, 22(1), 109-126. https://doi.org/10.5935/1980-690 6/psicologia.v22n1p109-126

Silva, D. I. Jr., Ferreira, M. C., \& Valentini, F. (2018). Evidências de validade da escala de autoeficácia de professores em amostras brasileiras [Validity evidences of the teacher self-efficacy scale in Brazilian samples self-efficacy in teachers]. Revista Psicologia: Organizações e Trabalho, 18(3), 405-411. https://doi.org/10.17652/rpot/201 8.3.13925

Simbula, S., Guglielmi, D., \& Schaufeli, W. B. (2011). A three-wave study on job resources, self-efficacy and work engagement among Italian schoolteachers. European Journal of Work and Organizational 
Psychology, 20(3), 285-305. https://doi.org/ 10.1080/13594320903513916

Siqueira, M. M. M., Gomide Jr., S., Moura, O. I., \& Marques, T. M. (1997). Um modelo pós-cognitivo para intenção de rotatividade: Antecedentes afetivos e cognitivos [Resumo] [A post-cognitive model for intended turnover: Affective and cognitive antecedents]. XXVI Interamerican Congress of Psychology, São Paulo.

Skaalvik, E. M., \& Skaalvik, S. (2007). Dimensions of teacher self-efficacy and relations with strain factors, perceived collective teacher efficacy, and teacher burnout. Journal of Educational Psychology, 99(3), 611-625. https://doi.org/10.1037/00 22-0663.99.3.611

Skaalvik, E. M., \& Skaalvik, S. (2014). Teacher self-efficacy and perceived autonomy: Relations with teacher engagement, job satisfaction, and emotional exhaustion. Psychological Reports, 114(1), 68-77. https:/ /doi.org/10.2466/14.02.PR0.114k14w0

Spector, P. E., \& Jex, S. M. (1998). Development of four self-report measures of job stressors and strain: Interpersonal Conflict at Work Scale, Organizational Constraints Scale, Quantitative Workload Inventory, and Physical Symptoms Inventory. Journal of Occupational Health Psychology, 3(4), 356-367. https://doi.org/10.1037/1076-899 8.3.4.356

Timms, C., Graham, D., \& Cottrell, D. (2007). "I Just Want to Teach": Queensland independent school teachers and their workload. Journal of Educational Administration, 45(5), 569-586. https://doi. org/10.1108/09578230710778204

van Wingerden, J., Derks, D., \& Bakker, A. B. (2017). The impact of personal resources and job crafting interventions on work engagement and performance. Human Resources Management, 56(1), 51-67. https: //doi.org/10.1002/hrm.21758

Xanthopoulou, D., Bakker, A. B., Demerouti, E., \& Schaufeli, W. B. (2007). The role of personal resources in the job demands- resources model. International Journal of Stress Management, 14(2), 121-141. https:// doi.org/10.1037/1072-5245.14.2.121

Xanthopoulou, D., Bakker, A. B., Demerouti, E., \& Schaufeli, W. B. (2009). Reciprocal relationships between job resources, personal resources, and work engagement. Journal of Vocational Behavior, 74(3), 235-244. https://doi.org/10.1016/j.jvb.2008 .11 .003

Zangenehvandi, M., Farahian, M., \& Gholami, H. (2014). On the relationship between teachers' critical thinking and self-efficacy. Modern Journal of Language Teaching Methods, 4(2), 286-293. http://iauksh.ac.ir/content/users/ user_iauksh/www.iauksh.ac.ir/admins/ rezome\%20asatid/farehyan/zangeneh, \%20farahian,\%20gholami.pdf

\section{Notes}

* Research article. 